\title{
HLA-DR3 and -DR4 control T-lymphocyte responses to mumps and Coxsackie B4 virus: studies on patients with Type 1 (insulin-dependent) diabetes and healthy subjects
}

\author{
$\varnothing$. Bruserud $^{1}$, J. Jervell ${ }^{2}$ and E. Thorsby ${ }^{1}$ \\ ${ }^{1}$ Institute of Transplantation Immunology and ${ }^{2}$ Medical Department, The National Hospital and University of Oslo, Oslo, Norway
}

\begin{abstract}
Summary. To study the relationships between the responses to viral antigens and the HLA-DR3 and -DR4 associations in Type 1 (insulin-dependent) diabetes mellitus, the frequency of T-lymphocyte proliferating in response to mumps, Coxsackie B4 and varicella-zoster antigens was determined. A decreased frequency was found in T lymphocytes able to respond to mumps or Coxsackie B4 when presented together with DR3, as compared with the frequency of $\mathrm{T}$ lymphocytes able to respond to these viruses together with other DR determinants. This was not found for varicella-zoster or purified protein de-
\end{abstract}

rivative of tuberculin. In contrast, an increased frequency was found in T lymphocytes responding to mumps or Coxsackie B4 together with DR4, compared with other DR determinants. The results were similar in Type 1 diabetic and healthy individuals. The results suggest that elements on the DR3 and DR4 molecules may control T-lymphocyte responses to mumps and Coxsackie B4 viruses.

Key words: Type 1 diabetes, T-lymphocyte responses, HLA-restriction, mumps, Coxsackie B4.
A positive association of Type 1 diabetes mellitus with HLA-DR3 and -DR4 has been established in many Caucasoid populations, while a negative association with DR2 is found [1,2]. The HLA molecules have an instrumental function in the activation of $\mathrm{T}$ lymphocyte immune responses [3]. For example, to activate T4 helper/amplifier lymphocytes, they have to recognize the antigen and the HLA class II molecules such as HLA$\mathrm{DR}$, in the membrane of antigen-presenting cells. Thus antigens can be recognized by $T$ lymphocytes only when presented together with HLA molecules. Different T-lymphocyte subpopulations respond when the same antigen is presented with different HLA-molecules. This is called self HLA restriction, the HLAmolecules functioning as the restriction elements for $\mathrm{T}$ lymphocyte activation.

Among the infections suspected, but not proven, to be important in the development of Type 1 diabetes are mumps [4, 5], Coxsackie B4 [6-9] and varicella-zoster [9] viral infections. Our study was performed to investigate whether the HLA-DR3 and -DR4 molecules have an antigen-specific regulatory function in the $\mathrm{T}$ lymphocyte response to any of these viruses.

\section{Subjects and methods}

\section{Cell donors.}

In a previous study we investigated the proliferative $T$ lymphocyte responses to mumps, Coxsackie B4, varicella-zoster and purified protein derivative of tuberculin in 44 healthy individuals [10] Because of technical reasons related to the limiting dilution assay (see below), 15 of these healthy individuals were selected, all expressing two defined DR-determinants and showing a relatively high response to the antigens tested. Details about these individuals are shown in Table 1. None had parents, siblings or children with Type 1 diabetes.

Sixty-four individuals with Type 1 diabetes were HLA typed. Seven carried DR3 or DR4 together with another defined DR-determinant. Only six of the seven patients showed a high proliferative response to the antigens, and these six, together with two DR3, 4 heterozygote patients also showing high responses, were tested in the limiting dilution assay. Clinical details of these patients are given in Table 2.

Neither the healthy individuals nor the diabetic patients had been vaccinated against mumps.

Table 1. Healthy individuals studied in the limiting-dilution assay of antigen-reactive $\mathrm{T}$ lymphocytes

\begin{tabular}{lllcccc}
\hline Identity & Sex & $\begin{array}{l}\text { Age } \\
\text { (years) }\end{array}$ & \multicolumn{2}{l}{ HLA } & & \\
\cline { 5 - 7 } & & & $\mathrm{A}$ & $\mathrm{B}$ & $\mathrm{C}$ & $\mathrm{DR}$ \\
\hline 1 & $\mathrm{~F}$ & 23 & $2 .-$ & 8.18 & & 1.3 \\
2 & $\mathrm{~F}$ & 36 & 1.3 & 7.8 & 1.3 \\
3 & $\mathrm{~F}$ & 34 & 1.3 & 7.8 & & 2.3 \\
$4^{1}$ & $\mathrm{~F}$ & 45 & 1.2 & 7.8 & & 2.3 \\
5 & $\mathrm{~F}$ & 60 & 1.2 & 7.8 & & 2.3 \\
$6^{2}$ & $\mathrm{~F}$ & 25 & 1.2 & 8.40 & & 3.8 \\
$7^{2}$ & $\mathrm{M}$ & 39 & 1.2 & 8.44 & $5 .-$ & 3.4 \\
8 & $\mathrm{~F}$ & 31 & 1.32 & 8.12 & & 3.4 \\
9 & $\mathrm{~F}$ & 28 & 19.28 & 12.14 & & 1.4 \\
$10^{2}$ & $\mathrm{M}$ & 39 & 9.11 & 15.35 & 3.4 & 1.4 \\
11 & $\mathrm{~F}$ & 25 & 3.9 & 7.27 & $2 .-$ & 2.4 \\
12 & $\mathrm{M}$ & 47 & 1.2 & 51.27 & 2.3 & 4.6 \\
$13^{2}$ & $\mathrm{~F}$ & 31 & 2.9 & $12 .-$ & & 4.7 \\
14 & $\mathrm{M}$ & 42 & 2.9 & 12.15 & $3 .-$ & 4.8 \\
$15^{2}$ & $\mathrm{~F}$ & 28 & 10.11 & 12.13 & & 4.8 \\
\hline
\end{tabular}

${ }^{1}$ Only tested for Coxsackie $\mathrm{B} 4 ;{ }^{2}$ only tested for mumps 
Table 2. Clinical data on the Type 1 diabetic patients included in the study

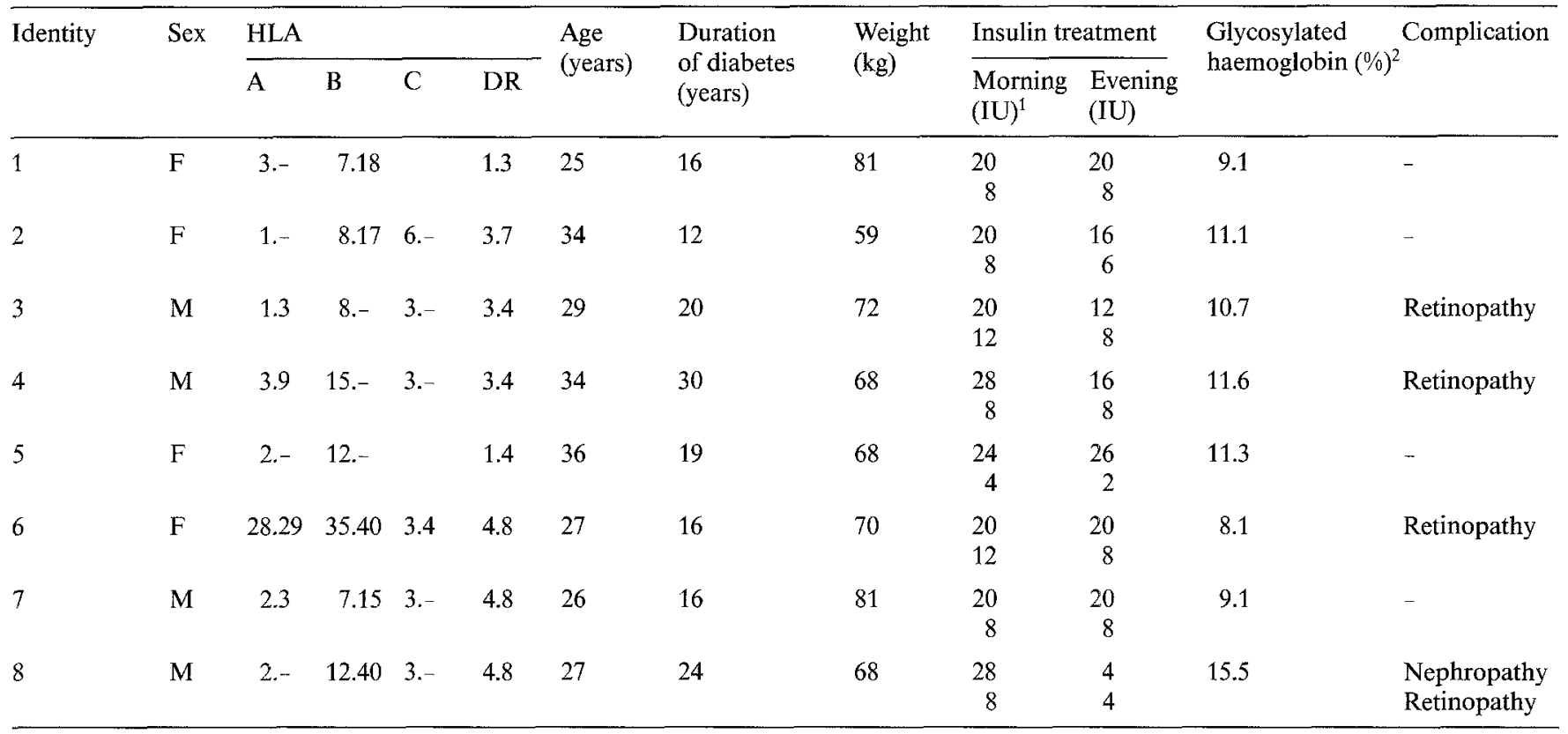

${ }^{1}$ Upper value is the dose of intermediate-acting insulin (Insulatard, Nordisk or Monotard, Novo), lower value the dose of rapid-acting insulin (Velosulin, Nordisk or Actrapid, Novo).

${ }^{2}$ Normal range $5-7.5 \%$.

STEP 1

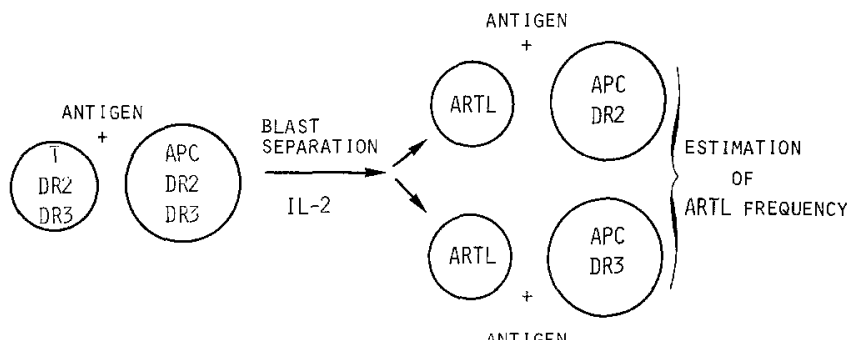

ANT I GEN

Fig. 1. Step 1: enriched antigen-specific $\mathrm{T}$ lymphocyte blasts from a DR heterozygous donor (DR2, DR3) are prepared from cultures of $T$ lymphocytes (T), autologous antigen-presenting cells (APC) and antigen. After 7 days of culture, antigen-specific $T$ lymphocyte blasts are recovered by Percoll density gradient separation. The blasts are further enriched by culture in the presence of Interleukin 2 (IL-2) for 6 days. Step 2: the frequency of antigen-reactive $T$ lymphocytes (ARTL) able to recognize antigen together with each DR determinant is estimated in a limiting dilution assay by mixing a variable number of ARTL with antigen and a constant number of allogeneic antigenpresenting cells sharing the one (DR2) or the other (DR3) determinant with the T lymphocyte donor

\section{Antigen preparations}

Two different mumps antigen preparations were used. The formaldehyde-inactivated mumps antigen was purchased from Behring (Mahrburg, FRG; batch $414538 \mathrm{~A}$ ) and is referred to as "mumps" antigen. The other preparation was purchased from MA Bioproducts (Walkersville, USA; batch 41234), inactivated by ultraviolet light as described previously [10] and referred to as "mumps V" antigen. Coxsackie B4 specific viral antigen (MA Bioproducts, batch 41433) was inactivated by ultraviolet light before use [10]. Formaldehyde-inactivated varicella-zoster viral antigen (Orion, Helsinki, Finland; batch G3) and purified protein derivative of tuberculin (Veterinary Institute,
University of Oslo, Norway) were also tested. The antigens were used in the following concentrations which have been found to be optimal [10]: mumps antigen: 1/2560, mumps $V$ antigen: 1/320, Coxsackie B4: $1 / 160$, varicella-zoster: $1 / 200$ and purified protein derivative of tuberculin: $2,5 \mu \mathrm{g} / \mathrm{ml}$.

The characteristics of the T-lymphocyte responses to the viral antigens are published elsewhere $[10,11]$. Briefly, the proliferative T lymphocyte response was maximal after 6-7 days of culture for all antigens. Control antigens, prepared from uninfected cells in the same manner as the corresponding viral antigens from infected cells, did not stimulate $T$ lymphocytes to proliferate. Neither the viral nor the control antigens stimulated proliferation of $T$ lymphocytes from neonates; i.e. they were not mitogenic.

\section{Preparation of Tlymphocytes and antigen-presenting cells}

The methods have been described in detail elsewhere [12]. Briefly, peripheral blood mononuclear cells were prepared from defibrinated blood by flotation over Ficoll-metrizoate (Lymphoprep; Nyegaard, Oslo, Norway). The mononuclear cells recovered from the interface were then rosetted with 2-aminoethylisothiouronium bromide-hydrobromide treated sheep erythrocytes and flotated over Ficoll-metrizoate. The non-rosetted cells at the interface were $\gamma$-irradiated 2400 rads and are then referred to as antigen-presenting cells. After lysis by autologous serum the cells in the pellet are referred to as $T$ lymphocytes.

\section{Preparation of enriched antigen-specific T-lymphocyte blasts}

The methods for preparing enriched antigen-specific $\mathrm{T}$ lymphocyte blasts have been described elsewhere [13-15] and are schematically il-

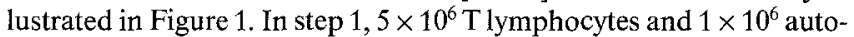
logous antigen-presenting cells were mixed with antigen in $16 \mathrm{ml}$ tissue culture medium (RPMI 1640 Gibco; Paisley, UK) supplemented with benzylpenicillin $(100 \mathrm{IU} / \mathrm{ml})$, streptomycin $(0.1 \mathrm{mg} / \mathrm{ml})$ and $20 \%$ inactivated pooled human serum. The cultures were incubated for 7 days at $37^{\circ} \mathrm{C}$ in a humidified atmosphere with $5 \% \mathrm{CO}_{2}$. The antigen- 
Table 3. The frequency of antigen-reactive T lymphocytes to mumps, Coxsackie B4, varicella-zoster and purified protein derivative of tuberculin (PPD)

\begin{tabular}{|c|c|c|c|c|c|c|}
\hline \multirow[t]{2}{*}{ Identity } & \multicolumn{2}{|l|}{ HLA-DR } & \multicolumn{4}{|c|}{ Antigen-reactive $\mathrm{T}$ lymphocyte frequency } \\
\hline & T-lymphocytes & $\begin{array}{l}\text { Antigen-presenting } \\
\text { cells }^{1}\end{array}$ & Mumps & Coxsackie B4 & Varicella-zoster & PPD \\
\hline Diabetic patient no. 1 & 1.3 & $\begin{array}{l}1(4) \\
3(4)\end{array}$ & $\begin{array}{c}1: 1148 \\
<1: 30000\end{array}$ & $\begin{array}{c}1: 1202 \\
<1: 30000\end{array}$ & $\begin{array}{l}1: 708 \\
1: 234\end{array}$ & $\begin{array}{l}1: 427 \\
1: 813\end{array}$ \\
\hline Healthy subject no. 5 & 2.3 & $\begin{array}{l}2(4) \\
3(8)\end{array}$ & $\begin{array}{l}1: 3311 \\
1: 15488\end{array}$ & $\begin{array}{l}1: 537 \\
1: 707\end{array}$ & $\begin{array}{l}1: 302 \\
1: 240\end{array}$ & $\begin{array}{l}1: 170 \\
1: 251\end{array}$ \\
\hline Diabetic patient no. 4 & 3.4 & $\begin{array}{l}3(2) \\
4(2)\end{array}$ & $\begin{array}{l}1: 3630 \\
1: 525\end{array}$ & $\begin{array}{l}1: 9337 \\
1: 1348\end{array}$ & $\begin{array}{l}1: 186 \\
1: 156\end{array}$ & $\begin{array}{l}1: 209 \\
1: 468\end{array}$ \\
\hline Healthy subject no. 9 & 1.4 & $\begin{array}{l}1(6) \\
4(7)\end{array}$ & $\begin{array}{l}1: 3090 \\
1: 269\end{array}$ & $\begin{array}{c}<1: 30000 \\
1: 436\end{array}$ & $\begin{array}{l}1: 282 \\
1: 550\end{array}$ & $\begin{array}{l}>1: 156 \\
>1: 156\end{array}$ \\
\hline
\end{tabular}

${ }^{1}$ HLA-DR antigens not shared with the corresponding T-lymphocytes are shown in parentheses

Table 4. Frequencies of mumps-specific antigen-reactive $\mathrm{T}$ lymphocytes (ARTL) in individuals tested with two different mumps antigen preparations

\begin{tabular}{|c|c|c|c|c|c|}
\hline \multicolumn{2}{|c|}{$\begin{array}{l}\text { T lymphocyte } \\
\text { donor }\end{array}$} & \multicolumn{2}{|c|}{$\begin{array}{l}\text { Mumps antigen } \\
\text { (Behring) }\end{array}$} & \multicolumn{2}{|c|}{$\begin{array}{l}\text { Mumps V antigen } \\
\text { (MA Bioproducts) }\end{array}$} \\
\hline Identity & HLA-DR & $\begin{array}{l}\text { HLA-DR } \\
\text { of APC }\end{array}$ & $\begin{array}{l}\text { Frequency } \\
\text { of ARTL }\end{array}$ & $\begin{array}{l}\text { HLA-DR } \\
\text { of APC }\end{array}$ & $\begin{array}{l}\text { Frequency } \\
\text { of ARTL }\end{array}$ \\
\hline \multicolumn{6}{|c|}{ Normal subjects } \\
\hline 1 & 1.3 & $\begin{array}{l}1(4) \\
3(4)\end{array}$ & $\begin{array}{r}>1: 156 \\
1: 1445\end{array}$ & $\begin{array}{l}1(4) \\
3(4)\end{array}$ & $\begin{array}{l}1: 512 \\
1: 16982\end{array}$ \\
\hline 3 & 2.3 & $\begin{array}{l}2(6) \\
3(6)\end{array}$ & $\begin{array}{r}1: 16238 \\
<1: 30000\end{array}$ & $\begin{array}{l}2(4) \\
3(7)\end{array}$ & $\begin{aligned} & 1: 5495 \\
< & 1: 20000\end{aligned}$ \\
\hline 6 & 3.8 & $\begin{array}{l}3(5) \\
\text { (4) } 8\end{array}$ & $\begin{array}{l}<1: 10000 \\
1: 2512\end{array}$ & $\begin{array}{l}3(4) \\
(4) 8\end{array}$ & $\begin{array}{l}1: 2630 \\
1: 1584\end{array}$ \\
\hline 9 & 1.4 & $\begin{array}{l}1(6) \\
4(7)\end{array}$ & $\begin{array}{l}1: 3090 \\
1: 269\end{array}$ & $\begin{array}{l}1(2) \\
4(6)\end{array}$ & $\begin{array}{l}1: 19498 \\
1: 625\end{array}$ \\
\hline 12 & 4.6 & $\begin{array}{l}\text { (1) } 4 \\
\text { (3) } 6\end{array}$ & $\begin{array}{c}1: 1778 \\
<1: 10000\end{array}$ & $\begin{array}{l}\text { (2) } 4 \\
\text { (5) } 6\end{array}$ & $\begin{array}{l}1: 831 \\
1: 8317\end{array}$ \\
\hline 15 & 4.8 & $\begin{array}{l}\text { (2) } 4 \\
\text { (3) } 8\end{array}$ & $\begin{array}{c}1: 5888 \\
<1: 30000\end{array}$ & $\begin{array}{l}\text { (2) } 4 \\
\text { (3) } 8\end{array}$ & $\begin{array}{l}1: 851 \\
1: 23442\end{array}$ \\
\hline \multicolumn{6}{|c|}{ Diabetic patients } \\
\hline 3 & 3.4 & $\begin{array}{l}\text { (2) } 3 \\
\text { (2) } 4\end{array}$ & $\begin{array}{l}1: 3630 \\
1: 525\end{array}$ & $\begin{array}{l}\text { (2) } 3 \\
\text { (2) } 4\end{array}$ & $\begin{array}{l}1: 871 \\
1: 331\end{array}$ \\
\hline 5 & 1.4 & $\begin{array}{l}1(3) \\
(2) 4\end{array}$ & $\begin{array}{l}1: 912 \\
1: 12589\end{array}$ & $\begin{array}{l}1(7) \\
\text { (2) } 4\end{array}$ & $\begin{array}{l}1: 776 \\
1: 6918\end{array}$ \\
\hline
\end{tabular}

1 APC: Antigen-presenting cells

responding $\mathrm{T}$ lymphocyte blasts were then recovered from the $40-50 \%$ interface of discontinous Percoll density gradients (Pharmacia, Uppsala, Sweden), the separation procedure being identical to that described by Berle et al. [14]. The blasts were further enriched by 6 days of culture in tissue culture medium supplemented with antibiotics as above, 10\% inactivated pooled human serum and $10 \%$ Interleukin 2-containing growth medium. The Interleukin 2-containing medium was produced as described previously [16]. The cells are then referred to as enriched $T$ lymphocyte blasts and were used in the limiting dilution assay (Fig. 1, step 2).

To get a measurable proliferative response when restimulating the blasts in the limiting dilution assay, the cells recovered after Percoll separation have to contain at least $50 \%$ blasts as judged by light microscopy $[13,14]$. To achieve this, only individuals showing a high proliferative response to the antigens were included in the study, corresponding to $>5000 \mathrm{cpm}$ when assayed [10].

\section{Limiting dilution assay and statistical methods}

Both the practical use of and the theoretical background for using the limiting dilution assay in calculating frequencies of antigen-reactive $T$ lymphocytes (ARTL) have been described elsewhere [13, 17, 18]. The method is schematically illustrated in Figure 1, step 2. Briefly, different numbers of enriched antigen-specific T lymphocyte blasts $(10000$, $5000,2500,1250,625,312$ or 156 cells/well) were cultured together with the corresponding antigen and $5 \times 10^{3}$ allogeneic antigen-presenting cells in each well of flatbottomed microtiter plates (Costar 3596; Cambridge, USA). The blasts were tested in parallel using antigen-presenting cells from two different donors, each sharing either the one or the other DR specificity with the T lymphocyte donor. Proliferation was judged by ${ }^{3} \mathrm{H}$-thymidine incorporation after 3 days.

For each concentration of T blasts tested, 24 wells were established with antigen and 12 wells without antigen for each of the two antigen-presenting cells tested. Of the 24 antigen stimulated cultures, positive scores were allotted to those in which ${ }^{3} \mathrm{H}$-thymidine incorporation exceeded the mean cpm $+3 \mathrm{SD}$ of the 12 corresponding antigen-free cultures. A well scored as positive according to this definition is considered to contain at least one ARTL. Assuming random distribution of ARTL, their number per well will follow the Poissons distribution. According to this, the frequency of ARTL will be the inverse number of enriched $\mathrm{T}$ blasts giving $37 \%$ negative cultures. A semi-logarithmic plot of $T$ blasts/well against the fraction of negative cultures fitted a straight line. Using these plots the frequency of ARTL could be calculated separately by regression analysis (least square solution) for the DR-determinant shared between the $T$ blasts and each of the allogeneic antigen-presenting cells in the re-stimulation (Fig.1, step 2).

Because of the Percoll separation and the blast enrichment, ARTL frequencies in different individuals should not be compared. Only the two ARTL frequencies calculated for each individual and each antigen should be compared.

Presentation of data. The data are presented as frequency of ARTL or as a relative ARTL frequency; $R$, which is defined as:

$$
\begin{aligned}
& \mathrm{R}_{\mathrm{DR} 3}=\frac{\text { frequency of DR3 restricted ARTL }}{\text { frequency of ARTL restricted by the other }} \\
& \text { DR determinant of the } \mathrm{T} \text { lymphocyte donor. }
\end{aligned}
$$

Thus, $R_{\mathrm{DR} 3}<1$ demonstrates a lower frequency of ARTL when antigen is recognized together with DR3. When the ARTL frequency only could be estimated, as for example $<1: 10^{4}$, this value was used in calculating the $R$ value.

The $R_{\mathrm{DR} 4}$-value was calculated correspondingly.

The Sign test was used for statistical analysis, and differences regarded statistically significant when $p<0.05$. 


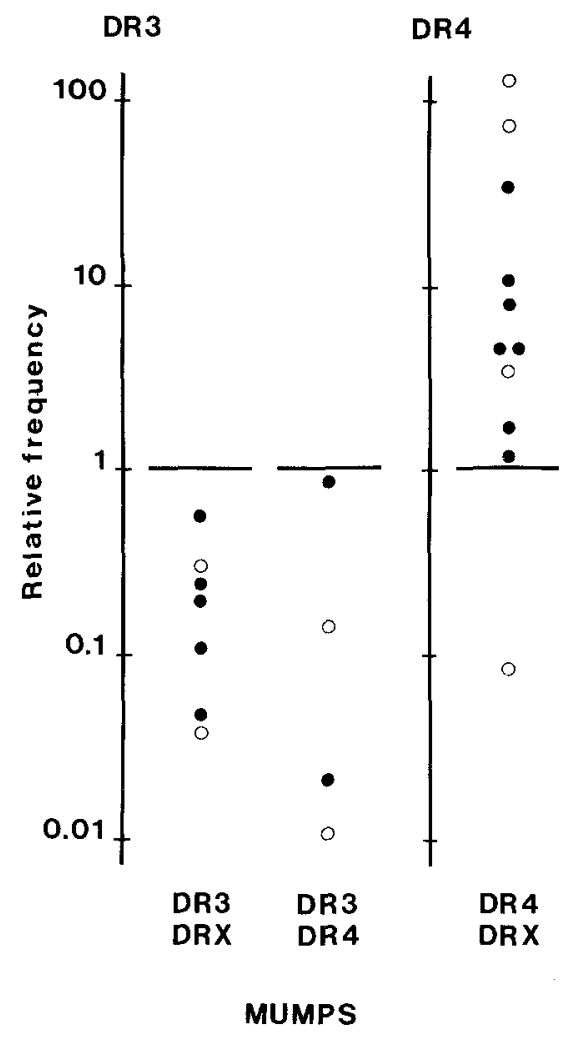

\section{Results}

\section{The frequency of mumps-specific ARTL}

Cells from eight diabetic and 14 healthy subjects were studied using the limiting dilution assay (Tables 3, 4; Fig. 2). For the experiments shown in Table 3 and Figure 2 , the mumps antigen purchased from Behring was used, whereas both mumps antigen preparations were used in the experiments shown in Table 4. For example, the frequency of $\mathrm{T}$ lymphocytes from patient 1 (DR1, 3-positive) able to respond to mumps together with DR1 was found to be 1:1148, while $<1: 30000 \mathrm{~T}$ lymphocytes responded to mumps together with DR3 $(\mathrm{R}=0.03$, Table 3$)$. Thus, the frequency of mumps-reactive T lymphocytes from a DR1, 3-positive donor was much higher when mumps was "seen" together with DR1 than DR3. In all 11 DR3-positive individuals (four diabetic and seven control subjects), a decreased frequency of $\mathrm{T}$ lymphocytes able to respond to mumps + DR3 (DR3-restricted ARTL) was found, compared with other $\mathrm{DR}$ determinants $\left(\mathrm{R}_{\mathrm{DR} 3}<1\right.$; $p=0.0005$, Fig. 2). In contrast, in 14 of the 15 DR4-positive individuals, an increased frequency of DR4 restricted ARTL ( $\left.\mathrm{R}_{\mathrm{DR} 4}>1\right)$ was found ( $p=0.0002$, Fig. 2$)$. The results were similar in diabetic and healthy individuals.

The two healthy DR2,3-heterozygotes tested both showed a decreased frequency of DR3-restricted ARTL to mumps compared with DR2-restricted ARTL; while the one DR2,4-heterozygote showed an increased frequency of DR4-restricted ARTL.
DR4

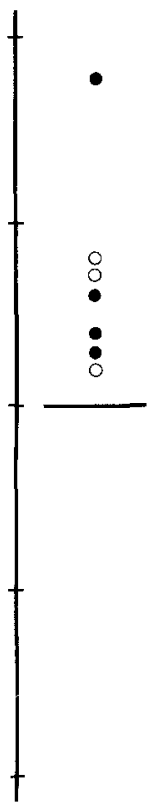

$\begin{array}{lll}\text { DR3 } & \text { DR3 } & \text { DR4 } \\ \text { DRX } & \text { DR4 } & \text { DR X }\end{array}$

COXSACKIE B4
Fig. 2. The relative frequency of $\mathbf{T}$ lymphocytes responding to mumps and Coxsackie B4 in healthy individuals (0) and Type 1 diabetic patients (o). $X=$ any other DR determinant than DR3 or DR4
To test the reproducibility of the results using the limiting dilution assay, eight individuals were studied using both the formaldehyde-inactivated mumps antigen (Behring) and the mumps V antigen (MA Bioproducts). These experiments were performed using two different blood samples separated by a time interval of approximately 6 months, and for each individual different donors of antigen-presenting cells were used in the two experiments (Table 4). For both antigen preparations, a decreased frequency of DR3-restricted ARTL was found in all DR3-positive subjects. An increased frequency of DR4-restricted ARTL was found using both antigenic preparations in all DR4-positives except one patient (no.5); the latter finding was reproducible. Thus, concordant results were found in all eight individuals using the two different mumps antigen preparations and different donors of antigen-presenting cells.

\section{The frequencies of Coxsackie B4 specific ARTL}

The results of some typical experiments using Coxsackie B4 are shown in Table 3, the overall results are shown in Figure 2. In eight of the $10 \mathrm{DR} 3$-positive individuals, a decreased frequency of DR3-restricted ARTL to Coxsackie B4 was found ( $p=0.0439$, Fig. 2). Nine out of ten DR4-positive individuals demonstrated an increased frequency of DR4-restricted ARTL ( $p=0.0098$, Fig. 2). Although fewer healthy individuals were suitable for testing with Coxsackie B4 than with mumps antigen, the results seemed to be similar in diabetic and healthy individuals. 
The three healthy DR2,3-heterozygotes all showed a decreased frequency of DR3-restricted ARTL to Coxsackie B4, while the one DR2,4-heterozygote showed an increased frequency of DR4-restricted ARTL.

\section{The frequency of ARTL specific for varicella-zoster or purified protein derivative of tuberculin}

No DR3-restricted hypo-responsiveness or DR4-restricted hyper-responsiveness was found for varicellazoster or purified protein derivative of tuberculin whether in the Type 1 diabetic patients or in the healthy individuals (data not shown).

\section{Discussion}

Our study demonstrates a decreased frequency of $\mathrm{T}$ lymphocytes reactive to mumps virus when the viral antigen is recognized together with HLA-DR3 in the antigen-presenting cells. In contrast, an increased frequency of DR4-restricted T lymphocytes reactive to mumps was found. Although fewer individuals were available for testing and the results were less significant then for mumps virus, a DR3-associated hypo-responsiveness and a DR4 associated hyper-responsiveness to Coxsackie B4 could be seen. No DR-associated hypo- or hyper-responsiveness to varicella-zoster or purified protein derivative of tuberculin was found, confirming the previous results of Scott et al. using a similar technique [13].

The estimation of ARTL frequencies could be made only after enrichment for ARTL blasts and restimulation in vitro. This was necessary to avoid allogeneic responses when using antigen-presenting cell donors expressing foreign HLA-DR determinants. This limited our study to individuals showing a relatively high response to the antigens.

In previous studies neither of the viral antigens was found to initiate a proliferative response of $T$ lymphocytes from neonates [10]. Thus, previous exposure to the viral antigen with enrichment in vivo of antigen-specific T lymphocytes is necessary for detecting a proliferative T-lymphocyte response in vitro. The individuals included in the present study all showed high responses to the viral antigens. All healthy and Type 1 diabetic individuals tested therefore had been previously sensitized against mumps and Coxsackie B4, probably following previous infection.

The data given in Table 4 demonstrate that our results using the limiting dilution assay are reproducible. Concerning the HLA-associated hypo- and hyper-responsiveness, the results were concordant for all individuals tested twice. The observed variations in the $R$ values were to be expected, because some variation will occur when using different mumps antigenic preparations. Concordant results were also found when Cox- sackie $B 4$ specific $T$ blasts from four individuals were retested during inhibition studies using monoclonal antibodies to different HLA-class II molecules [11].

Several explanations for our results are possible. First, differences in kinetics between DR3- and DR4-restricted ARTL, either in the primary culture (Fig.1, step 1) or during restimulation (step 2), could explain our results. However, in a previous study no differences in the kinetics of the response to mumps and Coxsackie B4 were found between DR3- and DR4-positive subjects [10], and this make the explanation less likely. Secondly, the cells recovered after Percoll separation contained a majority of blasts and less than $50 \%$ small lymphocytes. These small cells can be activated by the mitogen in Interleukin 2-containing growth medium during enrichment (step 2), and might theoretically be suppressive. However, compared with similar experimental models in mice we consider that a suppressive effect by this minority of mitogen-activated cells is not likely [19]. We therefore think that the most likely explanation for our results is a decreased number of DR3-restricted and an increased number of DR4-restricted ARTL undergoing blastoid transformation in primary mumps- and Coxsackie B4-stimulated cultures. The previously described tendency for hypo-responsiveness to mumps and Coxsackie B4 in DR3-positive subjects and hyperresponsiveness in DR4-positive individuals in primary cultures is in accordance with this explanation [11].

Type 1 diabetes is associated with certain high-risk HLA-haplotypes. Among these are the haplotypes expressing $\mathrm{A} 1 ; \mathrm{B} 8$;DR3, A30;B18,DR3 and A2;B15; DR4 [20]. Haplotype data are not available for the healthy individuals included in our study. It can be seen from Table 1 that a majority of the healthy DR3-positive individuals are positive for the A1-, B8- and DR3-determinants. The haplotype $\mathrm{A} 1 ; \mathrm{B} 8 ; \mathrm{DR} 3$ is the most common DR3-containing haplotype in the Norwegian population, and a majority of individuals positive for these three determinants will carry them on the same haplotype (unpublished data). The results in these healthy individuals may therefore reflect the immunoregulatory function of DR-associated restriction elements carried on diabetes-associated HLA-haplotypes.

As mentioned, our results were similar in both healthy individuals and Type 1 diabetic patients. This indicates that the hypo- and hyper-responsiveness to mumps and Coxsackie B4 are not the results neither from a continuing autoimmune process nor from poor metabolic control in the patients. Epidemiological studies have shown an increased risk of developing Type 1 diabetes in DR3,4 heterozygotes when compared with DR3 or DR4 homozygotes [2]. This indicates that the HLA-associated factor(s) responsible for development of Type 1 diabetes are different for DR3 and DR4, and may act synergistically in DR3,4 heterozygotes. Either the hypo-responsiveness to mumps and Coxsackie B4 associated with DR3, or the hyper-responsiveness associated with DR4, could be one of 
these HLA-linked predisposing factors. The true mechanism(s), however, is at present conjectural.

We want to emphasize that a viral aetiology in Type 1 diabetes has not been proven. However, our results are consistent with such a hypothesis. The role of the virus infection could be either to cause $\beta$-cell damage or to initiate an autoimmune process againt the $\beta$ cells. For several reasons an HLA-associated hypo-responsiveness to mumps and Coxsackie B4 might play a role in the development of Type 1 diabetes. First, both mumps and Coxsackie $B$ viruses are able to infect pancreatic $\beta$-cells in vitro [21, 22], and islet cell antibodies have been found to develop transiently during mumps infection [23]. Coxsackie viruses and the encephalo-myocarditis virus causing $\beta$-cell damage in the mouse are both picornaviruses [24]. The lower frequency of ARTL to mumps and Coxsackie B4 virus in association with DR3 could therefore make individuals carrying DR3 more vulnerable to infection of the $\beta$-cells with these viruses. Secondly, breast feeding protects against infections [25] and possibly against the development of Type 1 diabetes [26]. A short period of breast feeding [26], a decreased ability to produce the lymphokine Interleukin 2 [27] and a blank allele for the fourth complement factor [28] might all lead to a generally decreased defence against infections in patients with Type 1 diabetes. This might act synergistically with the DR3-associated, antigen-specific hypo-responsiveness in predisposing for $\beta$-cell damage. Thirdly, $40-60 \%$ of BB Wistar rats spontaneously develop a disease very similar to the Type 1 diabetes in man. BB Wistar rats are prone to develop infections [29] and are characterized by suppressed T lymphocyte functions [30]. Two additional genetic factors are both necessary for the development of diabetes: a lymphopenia inherited independently of the MHC of the rat, and a MHC-associated and as yet unknown factor [31]. An antigen-specific MHC-associated hypo-responsiveness is a possible candidate, similar to the DR3-associated hyporesponsiveness to mumps and Coxsackie B4 found in our studies.

T lymphocytes consist of several functional subsets [3]. The DR3-associated hypo-responsiveness might represent an alteration in one subset, not being counteracted by the relative hyper-responsiveness associated with other DR determinants (i.e. DR4). Rather, the DR4-associated hyper-responsiveness might be important for another step in the pathogenesis of Type 1 diabetes. In contrast, the relative hyper-responsiveness associated with DR2 in DR2,3 heterozygotes might be caused by a subset counteracting the DR3-associated hypo-responsiveness and thereby protecting against the development of Type 1 diabetes.

Type 1 diabetes is probably heterogenous, $\beta$-cell damage being the common denominator of different aetiologies. Immunoregulatory functions of HLA-DR3and DR4- associated restriction elements as described in this study may be important for the immune response to a postulated but still unproven viral aetiology (i.e. mumps, Coxsackie B4 or another virus). More studies are obviously needed to clarify this.

Acknowledgements. The study received financial support from The Norwegian Diabetes Foundation and the University of Oslo. We are very grateful to the diabetic patients for their cooperation. The advice of Dr. H. Scott, the technical assistance of M.Stenersen and the secretarial work of A. Mourier are gratefully acknowledged.

\section{References}

1. Svejgaard A, Platz P, Ryder LP (1983) HLA and disease 1982 - a survey. Immunol Rev 70: 193-218

2. Scholz S, Albert E (1983) HLA and disease: Involvement of more than one HLA-linked determinant of disease susceptibility. Immunol Rev 70:77-88

3. Thorsby E (1984) The role of HLA in T cell activation. Hum Immunol 9:1-7

4. Gamble DR (1980) Relation of antecedent illness to development of diabetes in children. Br Med J 281: 99-101

5. Schultz HA, Hart BA, Zielezny M, Schlesinger ER (1975) Is mumps virus an etiologic factor in juvenile diabetes mellitus? J Pediatr 86: 654-656

6. Yoon JW, Austin M, Onodera T, Notkins AL (1979) Virus-induced diabetes mellitus. Isolation of a virus from the pancreas of a child with diabetic ketoacidosis. New Engl J Med 300: 1173-1179

7. Gladisch R, Hoffmann W, Walden R (1976) Myokarditis and Insulitis nach Coxsackie-Virus-Infektion. Z Kardiol 65: 837-849

8. King ML, Bidwell D, Shaikh A, Banatwala JE (1983) Coxsackie B virus specific IgM responses in children with insuline-dependent (juvenile-onset, type 1) diabetes mellitus. Lancet 1:1397-1399

9. Jenson AB, Rosenberg HS, Notkins AL (1980) Pancreatic islet cell damage in children with fatal viral infections. Lancet 2: 354-358

10. Bruserud $\varnothing$, Thorsby E (1985) T lymphocyte responses to Coxsackie B4 and mumps virus. I. Influence of HLA-DR restriction elements. Tissue Antigens (in press)

11. Bruserud $\varnothing$, Stenersen M, Thorsby E (1985) T lymphocyte responses to Coxsackie B4 and mumps virus. II. Immunoregulation by HLA-DR3 and -DR4 associated restriction elements. Tissue Antigens (in press)

12. Albrechtsen D, Solheim BG, Thorsby E (1977) Serological identification of five HLA-D associated (Ia-like) determinants. Tissue Antigens 9: 153 159

13. Scott H, Hirschberg H, Thorsby E (1983) HLA-DR3 and -DR7 restricted $\mathrm{T}$ cell hyporesponsiveness to gluten antigens: a clue to the aetiology of coeliac disease. Scand J Immunol 18: 163-168

14. Berle EJ, Thoresen AB, Thorsby E (1982) HLA D/DR restriction of proliferative $\mathrm{T}$ cell responses to antigen. Tissue Antigens 20: 380-388

15. Kurnick JT, Altevogt $P$, Lindblom $P$, Sjoeberg $O$, Danneus I, Wigzell $\mathbf{H}$ (1980) Long term maintanance of HLA-D restricted T cells specific for soluble antigens. Scand J Immunol 11: 131-136

16. Bruserud Ø, Moen T (1984) Production of interleukin 2 containing growth medium for use in cloning of human T lymphocytes. J Immunol Meth 71: 175-184

17. van Oers MHJ, Pinkster J, Zeijlemaker WP (1978) Quantification of antigen-reactive cells among human $\mathrm{T}$ lymphocytes. Eur J Immunol 8: 477-484

18. Singal DP (1980) Quantitative studies of alloantigen-reactive human lymphocytes in primary and secondary MLC. Human Immunol 1: 67-76

19. Cooper J, Eichmann K, Fey K, Melchers I, Simon MM, Weltzien HV (1984) Network regulation among T cells: qualitative and quantitative studies of suppression in the non-immune state. Immunol Rev 79: 63-86

20. Contu L, Deschamps I, Lestradet H, Hors J, Schmid M, Busson M, Benajam A, Marcelli-Barge A, Dausset J (1982) HLA haplo- 
type study of 53 juvenile insulin-dependent diabetic (IDD) families. Tissue Antigens 20: 123-140

21. Prince GA, Jenson AB, Billups LC, Notkins AL (1978) Infection of human pancreatic $\beta$-cell cultures with mumps virus. Nature (London) 271: 158-161

22. Yoon JW, Onodera T, Jenson AB, Notkins AL (1978) Virus-induced diabetes mellitus. XI Replication of Coxsackie B3 virus in human pancreatic beta cell cultures. Diabetes $27: 778-781$

23. Helmke K, Otten A, Willems W (1980) Islet cell antibodies in children with mumps infection. Lancet 2: 211-212

24. Craighead JE, McLane MF (1968) Diabetes mellitus: induction in mice by encephalomyocarditis virus. Science 162:913-914

25. Saarinen UM (1982) Prolonged breast feeding as prophylaxis for recurrent otitis media. Acta Pediatr Scand 71: 567-571

26. Borch-Johnson K, Joner G, Mandrup-Poulsen T, Christy $M$, Zachau-Christiansen B, Kastrup K, Nerup J (1984) Relation between breast-feeding and incidence rates of insulin-dependent diabetes mellitus. Lancet 2: 1083-1086

27. Zier KS, Leo MM, Speilman RS, Baker L (1984) Decreased synthesis of Interleukin 2 in insulin-dependent diabetes mellitus. Diabetes 33: $552-555$

28. Marcelli-Barge A, Poirier JC, Schrind M, Deschamps I, Lestradet
H, Prevost P, Hors J (1984) Genetic polymorphism on the fourth component of complement and Type 1 (insulin-dependent) diabetes. Diabetologia 27: 116-117

29. Elder ME, MacLaren NK (1983) Identification of profound peripheral $\mathrm{T}$ lymphocyte immunodeficiencies in the spontaneously diabetic BB rat. J Immunol 130: 1723-1731

30. Prud'Homme GJ, Fuks A, Colle E, Seemayer TA, Guttman RD (1984) Immune dysfunction in diabetes-prone BB rats. Interleukin 2 production and other mitogen-induced responses are suppressed by activated macrophages. J Exp Med 159: 463-478

31. Jackson RA, Buse JB, Rifai R, Pelletier D, Milford EL, Carpenter CB, Eisenbarth GS, Williams RM (1984) Two genes required for diabetes in BB rats. J Exp Med 159: 1629-1636.

Received: 26 September 1984

and in revised form: 5 June 1985

Dr. Øystein Bruserud

Institute of Transplantation Immunology

Rikshospitalet

N-0027 Oslo 1

Norway 